DOI: $10.2478 / \mathrm{v} 10047-011-0036-3$

\title{
POSSIBILITIES OF DETECTING THE SPACE DEBRIS AND NEAR-EARTH ASTEROIDS BY LATVIAN OPTICAL AND RADIO TELESCOPES
}

\author{
M. Ābele ${ }^{1,2}$, L. Krūze ${ }^{1}$, \\ I. Shmeld ${ }^{1}$, I. Eglītis ${ }^{2}$, J. Kalvāns ${ }^{1}$ \\ ${ }^{1}$ Ventspils International Radio astronomy Center of Ventspils University College, \\ 101 Inženieru Str., Ventspils, LV-3601, LATVIA \\ ${ }^{2}$ Institute of Astronomy of University of Latvia, \\ 19 Raina Blvd., Riga, LV-1586, LATVIA
}

The paper considers the possibilities presented by the radio- and optical telescopes that Latvian astronomers have at their disposal for tracking the space debris and near-Earth asteroids as well as for detection of their reflected solar, radio and laser radiation. It is concluded that the Latvian telescopes are suitable for tracking, locating and ranging these objects, which allows the precision at determination of their orbit parameters to be improved.

Key words: Latvian radio- and optical telescopes, detection, space debris, near-Earth asteroids.

\section{INTRODUCTION}

Satellites and their parts which are no longer performing their function and are simply moving in orbits around the Earth (space debris - SD) are considered as dangerous objects. Their collisions with manned space vehicles can lead to lethal consequences. Collision of even a small asteroid with the Earth may also have fatal consequences. Therefore, the observations of these objects and calculation of their possible trajectories are very important in forecasting their collisions with satellites and the impact they would have upon the Earth.

This paper deals with the possibilities to track SD and near-Earth asteroids (NEA) by means of their laser and radio-location as well as detection of their reflected radiation, particularly solar light. The facilities which may be used by Latvian astronomers for these purposes - radio telescope RT-32 of the Ventspils International Radio Astronomy Center of the Ventspils University College (VIRAC) and Schmidt system telescope of the Institute of Astronomy of the Latvian University are reviewed.

\section{MAJOR RADIO AND OPTICAL TELESCOPES IN LATVIA}

\subsection{Radio telescope RT-32 of the Ventspils International Radio Astronomy Center (VIRAC)}

The radio telescope is situated at the VIRAC (Irbene, near Ventspils). Its main paraboloidal mirror with diameter $32 \mathrm{~m}$ reflects the radio waves to a secondary mirror of hyperboloid shape in the primary focus, which focuses them to 
the secondary focus where the receiver is placed. If the surfaces used as reflectors are close to ideal, the qualities of telescope are determined only by the diffraction of waves. We calculated the distribution of energy near the secondary focus by the method of numerical integration. The input aperture of the telescope was divided into separate elements, and their optical distance to the selected point on the focal surface of the secondary focus was calculated. Then the summation of the radio waves reflected by all elements of the main mirror was carried out, with taking into account their phase when reaching the focus at different points of the focal surface. As a result, the total value of energy at every point of this surface was obtained. Figure 1 shows the energy distribution on the focal surface for a point-like source with the wavelength $\lambda=60 \mathrm{~mm}$ (or frequency $5010 \mathrm{MHz}$ ). The accuracy of the surfaces of the telescope is $2-2.5 \mathrm{~mm}$ [2]. For $\lambda=60 \mathrm{~mm}$ this accuracy is $1 / 30$ of $\lambda$. Therefore, the theoretically calculated energy distribution is a good approximation. Dimensions of the image are less than $100 \mathrm{~mm}$, so it may arrive at the receiver with minimum losses. The pointing accuracy is $15^{\prime \prime}-20$ ", which is quite sufficient for pointing the telescope at the desired object.

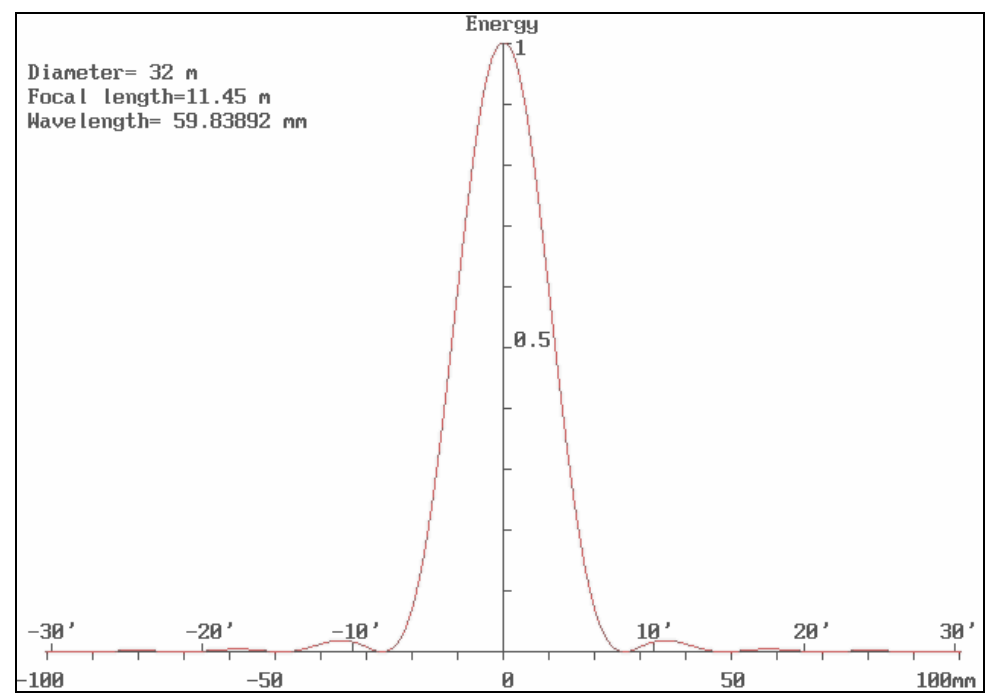

Fig. 1. Point image on the focal surface.

\subsection{Schmidt system telescope}

The Schmidt system telescope was erected in 1964 at Riekstukalns observation site of the Institute of Astronomy, the University of Latvia (the Radio Astrophysical observatory of Latvian Acad. Sci. until 2001) near Baldone. The diameter of the correction plate of telescope is $800 \mathrm{~mm}$, the diameter of the main mirror $-1200 \mathrm{~mm}$. The main mirror is mounted at a distance of $4780 \mathrm{~mm}$ from the correction plate. The reflecting surface of the mirror was restored in 2005. The image appears on the spherical surface of the main focus with a bend radius of $2400 \mathrm{~mm}$. Such is also the focal length of the system. If the surface of the chargecoupled device (CCD) matrix is less than $20 \mathrm{~mm}$, it can be placed in focus directly. If the size of CCD matrix is larger, a convex lens with the bend radius of $1000 \mathrm{~mm}$ should be placed in front of the matrix. 


\section{DETECTION OF SPACE DEBRIS AND NEAR-EARTH ASTEROIDS: ENERGY CONSIDERATIONS}

\subsection{Radio location}

The scheme of the radio location experiment is shown in Fig. 2.

A beam of radio-waves with power $E_{0}$ is sent by radio-telescope TRANS from the Earth to the observed object located at distance $L$. The diameter of the beam at this distance is $D_{\text {star }}$. Diameter $D_{0}$ of the object observed is usually smaller than $D_{\text {star }}$ so only a portion of the radiated energy reaches the object. Distribution of the energy in the beam is uneven because of diffraction.

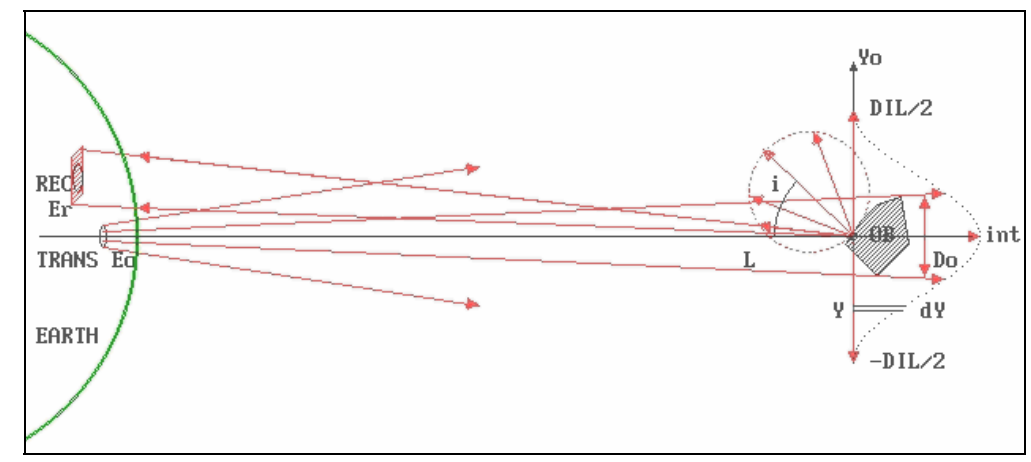

Fig. 2. Scheme of the radio location experiment.

The energy distribution in the object's plane $Y_{0}, Z_{0}$ was determined by the method of numerical integration. The distance of the point from the object's plane $Y_{0}, Z_{0}$ to the aperture of the TRANS point $y, z$ is the optical distance $\tau$ :

$$
\tau=\left(\left(y_{0}-y\right)^{2}+\left(z_{0}-z\right)^{2}+L^{2}\right)^{\frac{1}{2}} .
$$

The wavelength for transmitted radio waves at frequency $f$ is:

$$
\lambda=\frac{c}{f},
$$

where $c$ is the speed of light in vacuum.

The number of waves in the optical path is:

$$
N=\frac{\tau}{\lambda} \text {. }
$$

The phase of the wave is:

$$
\varphi=2 \pi(N-f i x(N)) \text {. }
$$

The coordinates of the phase vectors are:

$$
\xi=\cos (\varphi)
$$

and

$$
\eta=\sin (\varphi) .
$$


The resulting coordinates of the phase vectors are obtained by summing them for all points of the aperture:

$$
\xi_{s}=\sum_{i_{y}}^{n} \sum_{i_{z}}^{n} \xi
$$

and

$$
\eta_{s}=\sum_{i_{y}}^{n} \sum_{i_{z}}^{n} \eta
$$

where $i_{y}, i_{z}$ - the number of each element of the aperture, $n$ is their total number.

Only the elements with

$y^{2}+z^{2}\left\langle\frac{D_{\text {trans }}^{2}}{4}\right.$ (inside the aperture)

and

$$
\left.y^{2}+z^{2}\right\rangle \frac{d_{s e c}^{2}}{4} \text { (out of the secondary mirror), }
$$

were taken into account.

$D_{\text {trans }}$ is the aperture diameter of the telescope with transmitter, and

$d_{\text {sec }}$ is the diameter of its secondary mirror.

The power at a point with coordinates $Y_{0}, Z_{0}$ is:

$$
E_{\eta}=E_{\eta 0}\left(\xi_{s}^{2}+\eta_{s}^{2}\right)
$$

where $E_{\eta 0}$-coefficient of normalization (so that $E_{\eta}=1$ when $Y_{0}=Z_{0}=0$ ).

We performed calculations of the energy distribution at various distances $L$ from the Eupatoria radio-telescope for the frequency of $5010 \mathrm{MHz}$. The results exemplified for the transmitter near zone can be seen in Fig. 3.

As the object's diameter $D_{o b j}$ is much smaller than the radiated area, the power received by the object is:

$$
E_{p}=\frac{2 E_{m} \pi D_{o b j}^{2}}{4} .
$$

We assumed that the surface of an object is mat and it reflects according to the Lambert law.

The total radiation flux of energy reflected in the solid angle $d \Omega$ is:

$E_{r}=\frac{E_{p} a l \cos (i)}{\pi d \Omega}$,

where $a l-$ the reflection coefficient (albedo);

$i$ - the reflection angle $\left(i=45^{\circ}\right.$ on the average);

$\pi=3.14159$. 


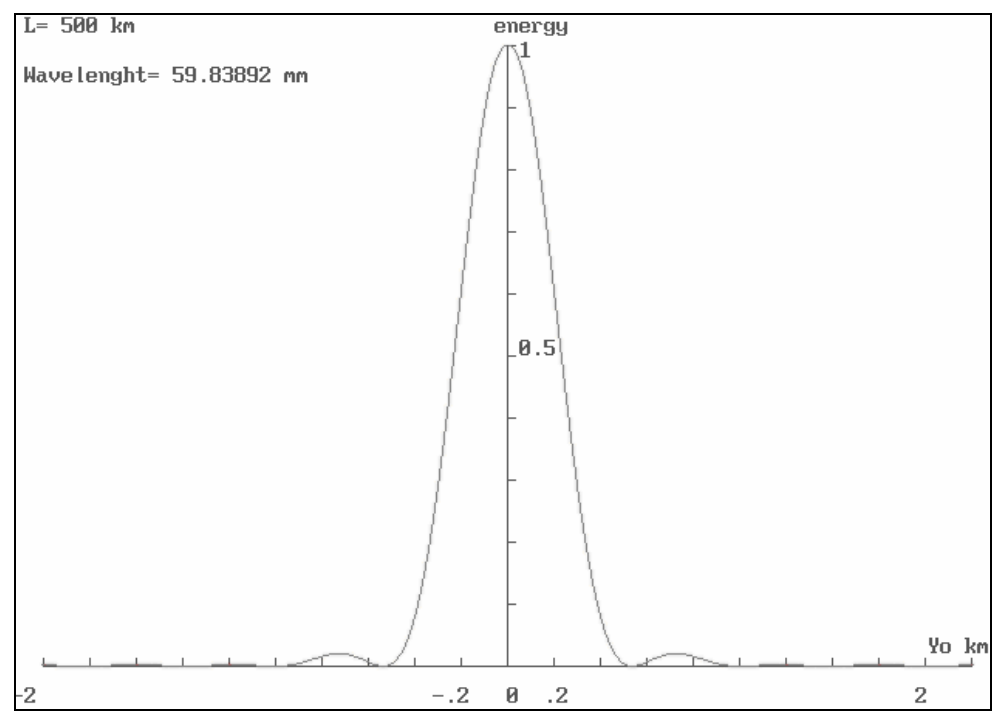

Fig. 3. The power received on the plane of object observed $v$ s. coordinate $Y_{0}$.

The solid angle of object as seen from the receiver is:

$$
d \Omega=\frac{\pi D_{o b j}^{2}}{4 L^{2}}
$$

and the total power reaching the receiver is simply the product of its aperture square and $E_{p}$.

Following [3], we assumed the transmitter power and diameter of the Eupatoria telescope to be $60 \mathrm{KW}$ and $70 \mathrm{~m}$, respectively, and calculated the average values of the received power during the radio location of variously sized objects at different distances. The results for the Irbene radio telescope RT-32 at frequency $5050 \mathrm{MHz}$ are shown in Tables $1 \mathrm{a}$ and $1 \mathrm{~b}$.

Table $1 a$

Power received during the radio location by RT-32 of variously sized objects at different distances ( $a l=0.9$ for metallic debris)

\begin{tabular}{|c|r|r|r|r|r|}
\hline $\begin{array}{c}\text { Objects } \\
\text { diameter, } \mathrm{m}\end{array}$ & 0.05 & 0.25 & \multicolumn{1}{|c|}{1.25} & 6.25 & 31.25 \\
\hline Range, $\mathrm{km}$ & \multicolumn{6}{|c|}{ Received power 1e-18 W units } \\
\hline 500 & 458282 & 11457070 & 286426769 & 7160669246 & 179016731172 \\
\hline 1000 & 28642 & 716066 & 17901673 & 447541827 & 11188545698 \\
\hline 2000 & 1790 & 44754 & 1118854 & 27971364 & 699284106 \\
\hline 4000 & 111 & 2797 & 69928 & 1748210 & 43705256 \\
\hline 8000 & 6 & 174 & 4370 & 109263 & 2731578 \\
\hline 16000 & 0 & 10 & 273 & 6828 & 170723 \\
\hline 32000 & 0 & 0 & 17 & 426 & 10670 \\
\hline 64000 & 0 & 0 & 1 & 26 & 666 \\
\hline 128000 & 0 & 0 & 0 & 1 & 41 \\
\hline 256000 & 0 & 0 & 0 & 0 & 2 \\
\hline
\end{tabular}


Power received during the radio location by RT-32 of variously sized objects at different distances $(a l=0.1$ for asteroid)

\begin{tabular}{|r|r|r|r|r|r|}
\hline $\begin{array}{c}\text { Objects } \\
\text { diameter, } \mathrm{m}\end{array}$ & \multicolumn{1}{|c|}{10} & 50 & \multicolumn{1}{|c|}{250} & 1250 & 6250 \\
\hline Range, $\mathrm{km}$ & \multicolumn{5}{|c|}{ Received power 1e-18 W units } \\
\hline 500 & 203930 & 5098258 & 127456453 & 3186411346 & 79660283652 \\
\hline 1000 & 12745 & 318641 & 7966028 & 199150709 & 4978767728 \\
\hline 2000 & 796 & 19915 & 497876 & 12446919 & 311172983 \\
\hline 4000 & 49 & 1244 & 31117 & 777932 & 19448311 \\
\hline 8000 & 3 & 77 & 1944 & 48620 & 1215519 \\
\hline 16000 & 0 & 4 & 121 & 3038 & 75969 \\
\hline 32000 & 0 & 0 & 7 & 189 & 4748 \\
\hline 64000 & 0 & 0 & 0 & 11 & 296 \\
\hline 128000 & 0 & 0 & 0 & 0 & 18 \\
\hline 256000 & 0 & 0 & 0 & 0 & 1 \\
\hline
\end{tabular}

Therefore the available equipment makes it possible to observe also the nearEarth asteroids (NEAs).

\section{2. Calculation of the brightness of observed objects}

To evaluate the possibility to perform optical observations of the objects in order to determine their angular coordinates, it is necessary to know their brightness. The optical observations can only be done if the object is illuminated by the Sun or a ground-based laser.

\subsubsection{Illumination by the Sun}

The apparent solar magnitude is $m_{0}=-26.8$ [4]. The flux of solar energy at the distance of the Earth orbit is $S_{\text {sol }}=1360 \mathrm{Js} / \mathrm{m}^{2}$.

For an object with diameter $D_{o b j}$ the received power of the solar light is:

$$
E_{s o l}=\frac{S_{s o l} \pi D_{o b j}^{2}}{4} .
$$

The object with the reflection coefficient al (albedo) at distance $L$ illuminates the Earth, and the illuminance is:

$$
E_{L}=\frac{E_{\text {sol }} a l \cos (i)}{\pi L^{2}}
$$

From Pogson's formula [4] it is possible to calculate the stellar magnitude of the celestial body:

$$
m=m_{0}-\log \left(\frac{E_{\text {sol }}}{S_{\text {sol }}}\right) \text {. }
$$


For observations of this kind, the Schmidt system's telescope located at Baldone could successfully be used. The calculated stellar magnitudes for different SD and NEA and illumination they generate on the Earth surface are given in Tables $2 \mathrm{a}$ and $2 \mathrm{~b}$. The atmospheric transmittance is assumed to be 0.8 , and the albedo -0.9 for metallic space debris bodies and 0.1 for NEA.

Table $2 a$

Estimated stellar magnitudes of space debris metallic bodies (Schmidt telescope)

\begin{tabular}{|c|c|c|c|c|c|}
\hline $\begin{array}{c}\text { Objects } \\
\text { diameter, } \mathrm{m}\end{array}$ & 0.05 & 0.25 & 1.25 & 6.25 & 31.25 \\
\hline Range, $\mathrm{km}$ & \multicolumn{5}{|c|}{ Magnitude } \\
\hline 500 & 10.45 & 6.97 & 3.46 & -0.03 & -3.52 \\
\hline 1000 & 11.95 & 8.46 & 4.96 & 1.47 & -2.02 \\
\hline 2000 & 13.46 & 9.96 & 6.47 & 2.97 & -0.51 \\
\hline 4000 & 14.96 & 11.47 & 7.97 & 4.48 & 0.99 \\
\hline 8000 & 16.47 & 12.97 & 9.48 & 5.99 & 2.49 \\
\hline 16000 & 17.97 & 14.48 & 10.99 & 7.49 & 4 \\
\hline 32000 & 19.48 & 15.99 & 12.49 & 9 & 5.5 \\
\hline 64000 & 20.99 & 17.49 & 14 & 10.05 & 7.01 \\
\hline 128000 & 22.49 & 19 & 15.5 & 12.01 & 8.51 \\
\hline 256000 & 24 & 20.5 & 17.01 & 13.51 & 10.02 \\
\hline 512000 & 25.5 & 22.01 & 18.51 & 15.02 & 11.52 \\
\hline 1024000 & 27.01 & 23.51 & 20.02 & 16.52 & 13.03 \\
\hline 2048000 & 28.51 & 25.02 & 21.52 & 18.03 & 14.53 \\
\hline 4096000 & 30.02 & 26.52 & 23.03 & 19.53 & 16.04 \\
\hline
\end{tabular}

Table $2 b$

Estimated illumination generated on the Earth surface by NEA (Schmidt telescope)

\begin{tabular}{|r|c|c|c|c|c|}
\hline $\begin{array}{c}\text { Objects } \\
\text { diameter, } \mathrm{m}\end{array}$ & 10 & 50 & 250 & 1250 & 6250 \\
\hline Range, $\mathrm{km}$ & \multicolumn{5}{|c|}{ Illumination of the Earth surface $1 \mathrm{e}-18 \mathrm{~W} / \mathrm{m}^{-2}$} \\
\hline 500 & 6.33 & 2.83 & -0.65 & -4.15 & -7.64 \\
\hline 1000 & 7.83 & 4.34 & 0.84 & -2.64 & -6.13 \\
\hline 2000 & 9.34 & 5.84 & 2.35 & -1.13 & -4.63 \\
\hline 4000 & 10.84 & 7.35 & 3.86 & 0.36 & -3.12 \\
\hline 8000 & 12.35 & 8.86 & 5.36 & 1.87 & -1.62 \\
\hline 16000 & 13.86 & 10.36 & 6.87 & 3.37 & -0.11 \\
\hline 32000 & 15.36 & 11.87 & 8.37 & 4.88 & 1.38 \\
\hline 64000 & 16.87 & 13.37 & 9.88 & 6.38 & 2.89 \\
\hline 128000 & 18.37 & 14.88 & 11.38 & 7.89 & 4.39 \\
\hline 256000 & 19.88 & 16.38 & 12.89 & 9.39 & 5.9 \\
\hline 512000 & 21.38 & 17.89 & 14.39 & 10.9 & 7.4 \\
\hline 1024000 & 22.89 & 19.39 & 15.9 & 12.4 & 8.91 \\
\hline 2048000 & 24.39 & 20.9 & 17.4 & 13.91 & 10.41 \\
\hline 4096000 & 25.9 & 22.4 & 18.91 & 15.41 & 11.92 \\
\hline
\end{tabular}




\subsubsection{Recording of a moving object using CCD camera}

The Schmidt system telescope at Baldone is equipped with the Santa Barbara company's wire bonder ST - 10XE/XME CCD Imaging Camera.

The determination of the angular coordinates of a moving celestial body is possible if there are at least 4 images of stars with known coordinates on the picture. So the telescope must follow the stars and the image of SD or NEA is moving on the focal plane and on the surface of CCD matrix.

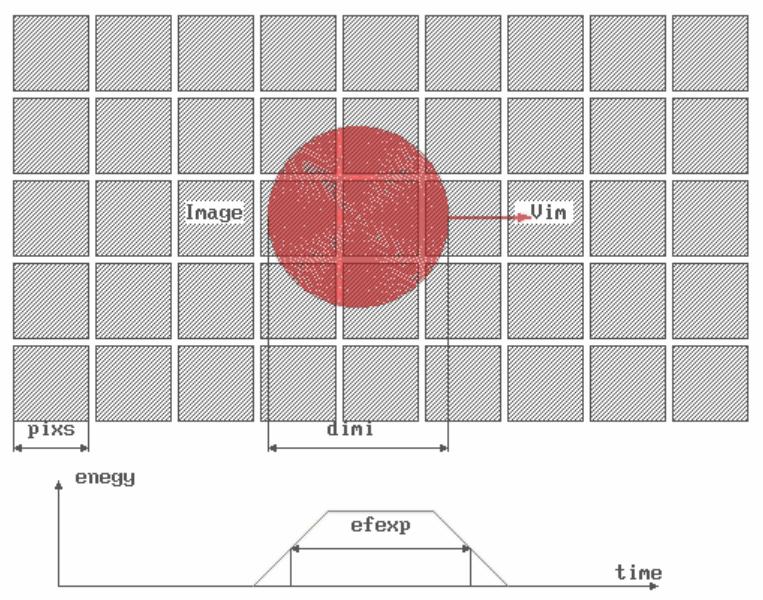

Fig. 4. Moving image on the CCD surface.

For a satellite of the Earth or its shiver its orbital speed (in the case of a circular orbit) depends on the height $(H)$ above the ground level:

$$
V_{o r b}=V_{E}\left(\frac{R_{E}}{\left(R_{E}+H\right)}\right)^{\frac{1}{2}} \text {. }
$$

Here $V_{E}=7900 \mathrm{~m} / \mathrm{s}$ is the orbital speed on the Earth surface,

$R_{E}=6378 \mathrm{~km}$ is the equatorial radius of the Earth.

The maximum velocity of an object is reached when it is in the zenith. Then the object's image moves on the focal plane with the speed:

$$
V_{i m}=\frac{V_{o b j} F}{H},
$$

where $F$ is the focal length of the camera.

Figure 4 shows a part of the matrix surface with the object's image which moves over this surface with the speed $V_{i m}$.

The power passing through the telescope is:

$$
E_{t}=\frac{E_{L} \pi \rho\left(D^{2}-d^{2}\right)}{4},
$$

where $\rho=0.8$ is the optical permeability of the telescope, 
$D$ is the diameter of the telescope.

$d$ is the size of the cassette holder.

At the image diameter $D_{i m i}$ one pixel of the CCD matrix receives the power:

$E_{p}=\frac{4 E_{t} L_{p i x s}^{2}}{\left(\pi D_{i m i}^{2}\right)}$.

When the image moves on the matrix surface, a pixel in its pass is exposed no longer than:

$t_{\text {eff }}=\frac{D_{i m i}}{V_{i m}}$.

During this time, one pixel of the matrix receives the energy:

$E_{e}=E_{p} t_{e f f}$.

Since this energy is small, it is more demonstrative to measure it as the number of photons. The energy of a photon can be calculated with Planck's law:

$E_{f o}=h v$,

where $h=6.6252 \cdot 10^{-34}$ is Planck's constant;

$v=\frac{c}{\lambda}$ is the frequency at wavelength $\lambda$.

The number of electrons generated by these photons is:

$n_{f o}=E_{f o} Q_{e f}$,

where $Q_{e f}$ is the absolute quantum efficiency of the CCD matrix.

Table 3

Number of photoelectrons for 1 pixel of CCD

\begin{tabular}{|c|r|r|r|r|r|}
\hline $\begin{array}{c}\text { Objects } \\
\text { diameter, } \mathrm{m}\end{array}$ & 0.05 & 0.25 & 1.25 & 6.25 & 31.25 \\
\hline Range, $\mathrm{km}$ & \multicolumn{5}{|c|}{ Photoelectrons } \\
\hline 500 & 43 & 1089 & 27225 & 680636 & 17015913 \\
\hline 1000 & 21 & 547 & 13676 & 341903 & 8547581 \\
\hline 2000 & 11 & 276 & 6902 & 172558 & 4313973 \\
\hline 4000 & 5 & 140 & 3517 & 58933 & 2198325 \\
\hline 8000 & 2 & 73 & 1828 & 45718 & 1142972 \\
\hline 16000 & 1 & 39 & 993 & 24839 & 620988 \\
\hline 32000 & 0 & 24 & 600 & 15022 & 375555 \\
\hline 64000 & 0 & 20 & 517 & 12929 & 323242 \\
\hline 128000 & 0 & 23 & 583 & 14599 & 364978 \\
\hline 256000 & 0 & 1 & 38 & 971 & 24278 \\
\hline 512000 & 0 & 0 & 7 & 177 & 4440 \\
\hline 1024000 & 0 & 0 & 1 & 39 & 978 \\
\hline 2048000 & 0 & 0 & 0 & 9 & 231 \\
\hline 4096000 & 0 & 0 & 0 & 2 & 56 \\
\hline 8192000 & 0 & 0 & 0 & 0 & 13 \\
\hline
\end{tabular}


The results of calculations for the Schmidt telescope (Baldone) are given in Table 3. The diameter of the image is taken $30 \mu \mathrm{m}$, the transmittance of telescope and atmosphere -0.8 , albedo of SD -0.9 , average wavelength $-550 \mathrm{~nm}$, and the quantum efficiency -0.4 . The practical experience shows that to reliably register an object it is necessary to accumulate more than 20 electrons.

\section{LASER LOCATION OF CD AND NEA}

Laser location may be used to determine the angular coordinates of nearEarth space objects and also for measuring the distance to them. Several companies are known to be producing high-power lasers which can be used for this purpose, e.g. EKSPLA Co. (Lithuania). Their products are successfully used at the GeoDynamics Observatory of the Institute of Astronomy of the University of Latvia (IAUL) as well as at the Institute of Geo-Informatics in Riga. For directing a laser beam to the observed object a telescope-reflector has been made at the IAUL [5].

The telescope is used to concentrate the light radiated by a laser in a narrow beam as much as possible, to be then directed to the desired object. Dispersion of the beam is limited by diffraction like in the radio range (Section 3.1) The wavelengths in the optical range are much smaller, therefore in the calculations of phase displacement from different laser telescope aperture points by Eq. (1) it is necessary first to find the optical path $\tau$ via Taylor's series, assuming $y, z<<L$ :

$$
\tau=L+\frac{1}{2 L}\left(\left(y_{0}-y\right)^{2}+\left(z_{0}-z\right)^{2}\right) .
$$

Further calculations can be done with Eqs. (2-10) to find the distribution of illumination $E_{0}$ at distance $L$ as a function of the distance from the $y_{0}$-axis. This distribution is shown in Fig. 5 for the distance to the object being $500 \mathrm{~km}$ and highpower laser working at $\lambda=1006 \mathrm{~nm}$.

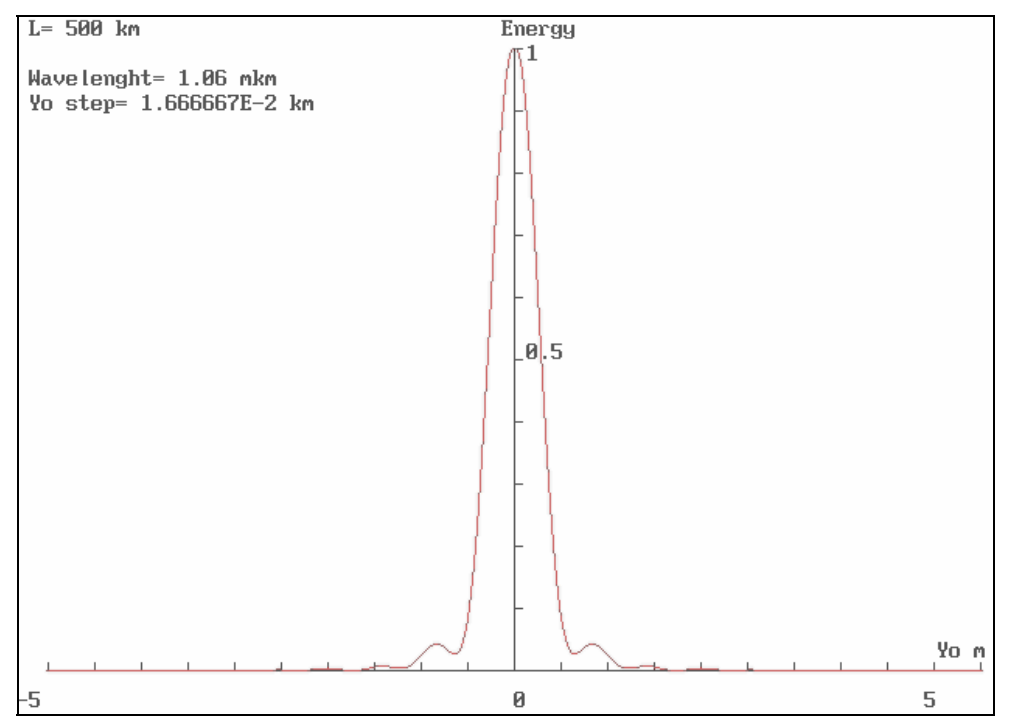

Fig. 5. Area of illumination $E_{0}$ at distance $500 \mathrm{~km}$ as a function of the distance from the $y_{0}$-axis (laser wavelength $\lambda=1006 \mathrm{~nm}$ ). 
In this case the diameter of the illuminating beam is comparable with the object sizes. The energy received by the target during laser pulse is:

$$
E_{\text {rec }}=\int_{0}^{\frac{1}{2} D_{o b j}} E_{0}(r) r d r,
$$

where $D_{o b j}$ is the diameter of the target object supposing that it is round.

Portion of the energy received by the target object $\frac{E_{r e c}}{E_{0}}$ is shown in Fig. 6 as a function of $D_{o b j}$.

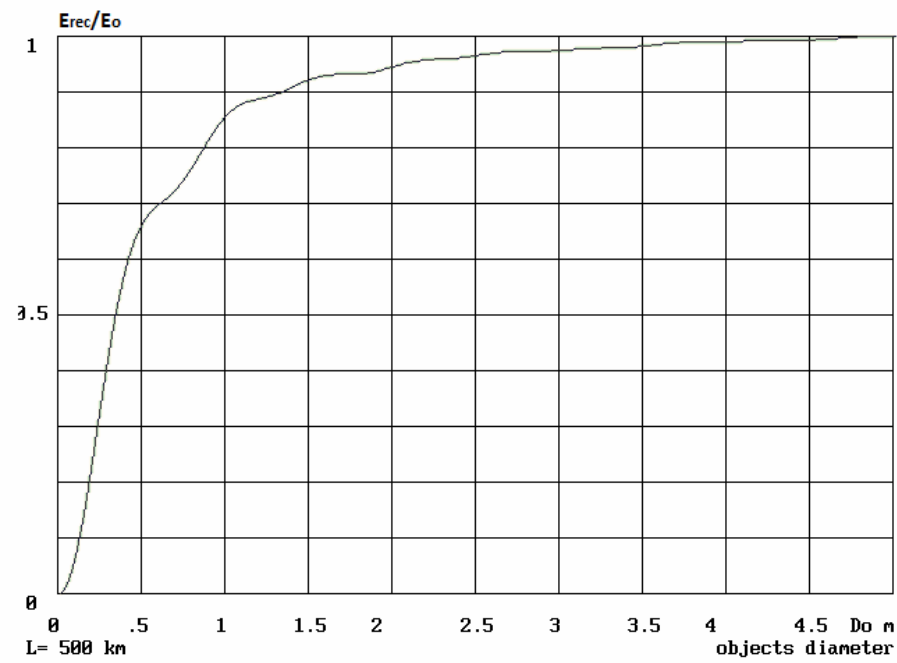

Fig. 6. Portion of the energy received by the target object.

In a similar way as in the case of the radio waves (Eq. 14) it is possible to calculate the energy reflected by the target during the laser pulse and reaching the Earth surface (per surface unit):

$$
E_{L}=\frac{E_{r e c} a_{l} \cdot \kappa_{a t m} \cdot \cos (i)}{\pi L^{2}},
$$

where $a_{l}$-reflection coefficient;

$\kappa_{a t m}-$ atmospheric permeability;

$i \quad$ - average reflection angle (as usual we assume $i=45^{\circ}$ ). is:

The energy passing through the telescope used to register the reflected light

$$
E_{r}=\frac{E_{L} \pi \cdot \kappa_{o p t}\left(D^{2}-d^{2}\right)}{4} .
$$

Here: $\kappa_{o p t}-$ permeability of the optics,

$D$ - diameter of the telescope aperture,

$d$ - diameter of its secondary mirror. 
Receivers for the infra-red range are produced on the basis of indium and gallium arsenide [6]. A good example is camera SU640KTSX - 1.7RT of the GOODRICH company with a quantum efficiency of 0.8 electrons from a photon at wavelength 1000-1700 nm. As a receiver, telescope TPL-1 [7] could be used (available in Riga, Potsdam, Metsahovi (Finland) and in several observatories of the Ukraine).

Telescope TPL-1 in Riga and its main mirror were renovated in 2007. It is planned, together with specialists from Finland, to improve also its optical system. The number of photons from target during a laser pulse is:

$$
N_{p}=\frac{E_{r} C_{f i} \cdot Q_{e f}}{E_{f o}} \text {.replace } C_{f i} \text { by } \kappa_{o p t}
$$

where: $\kappa_{o p t}-$ permeability of the telescope optics,

$Q_{e f}$ - the quantum efficiency of the CCD matrix,

$E_{f o}-$ the energy of photons.

Photoelectrons registered during laser pulse (space debris)

\begin{tabular}{|c|r|r|r|r|r|}
\hline $\begin{array}{c}\text { Objects } \\
\text { diameter, } \mathrm{m}\end{array}$ & 0.05 & 0.25 & 1.25 & 6.25 & 31.25 \\
\hline Range, $\mathrm{km}$ & \multicolumn{5}{|c|}{ Photoelectrons } \\
\hline 500 & 5289 & 111973 & 758045 & 1051227 & 1075909 \\
\hline 1000 & 264 & 6531 & 120364 & 216629 & 232483 \\
\hline 2000 & 66 & 330 & 10738 & 45496 & 55442 \\
\hline 4000 & 4 & 16 & 662 & 9534 & 13155 \\
\hline 8000 & 1 & 4 & 53 & 933 & 3069 \\
\hline 16000 & 0 & 1 & 5 & 60 & 673 \\
\hline 32000 & 0 & 0 & 0 & 3 & 84 \\
\hline 64000 & 0 & 0 & 0 & 0 & 6 \\
\hline 128000 & 0 & 0 & 0 & 0 & 0 \\
\hline
\end{tabular}

Photoelectrons registered during laser pulse (NEA)

\begin{tabular}{|c|r|r|r|r|r|}
\hline $\begin{array}{c}\text { Objects } \\
\text { diameter, } \mathrm{m}\end{array}$ & 10 & 50 & 250 & 1250 & 6250 \\
\hline Range, $\mathrm{km}$ & \multicolumn{5}{|c|}{ Photoelectrons } \\
\hline 500 & 939 & 1163 & 1195 & 1195 & 1195 \\
\hline 1000 & 128 & 273 & 298 & 298 & 298 \\
\hline 2000 & 9 & 59 & 73 & 74 & 74 \\
\hline 4000 & 0 & 10 & 17 & 18 & 18 \\
\hline 8000 & 0 & 0 & 3 & 4 & 4 \\
\hline 16000 & 0 & 0 & 0 & 1 & 1 \\
\hline 32000 & 0 & 0 & 0 & 0 & 0 \\
\hline
\end{tabular}


The number of the registered photons for different SD sizes and distances is given in Tables $4 \mathrm{a}$ and $4 \mathrm{~b}$. The wavelength of laser is taken $1006 \mathrm{~nm}$, laser pulse energy is $1 \mathrm{~J}$, the atmosphere, optics and filter transmittance: $0.8,0.7$ and 0.5 , respectively. We assumed albedo to be 0.9 for SD and 0.1 for NEA, and the quantum efficiency of the CCD matrix -0.8 .

\section{NEA LASER RANGING}

The scheme of distance measurements by a laser range-finder is shown in Fig. 7.

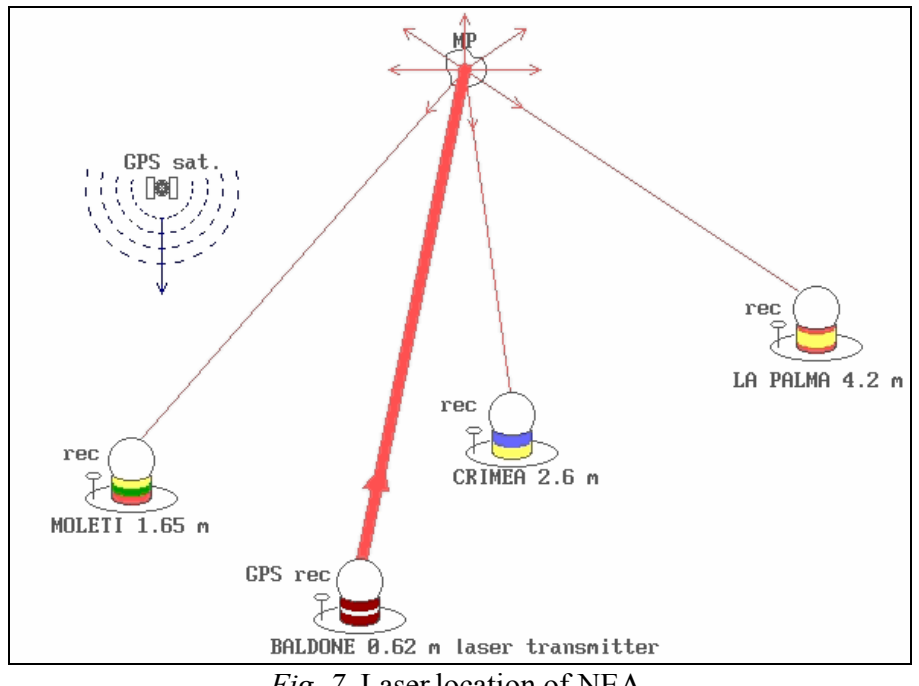

For more details see [8-10]. When using only the classic angular measurements of coordinates, usually the precision of forecasting the coordinates for the dangerous NEA is about million of kilometers. If the distance and radial speed measurements are added, the precision of several hundreds of kilometers can be reached.

\section{CONCLUSIONS}

The characteristics of the facilities which are at the disposal of Latvian astronomers and the possibilities provided by the former as to detection of the reflected by SD and NEA radiation during their laser and radio location are suitable for tracking the mentioned objects, their laser and radio location and ranging. For optical wavelengths also solar illumination for such a tracking can be used. If the laser and radio ranging data are added to the classical angular measurements, the precision of forecasting the SD and NEA coordinates could be improved substantially.

\section{Aknowledgement}

This paper is supported by European Social Fund, project "Signals related to Artificial Earth Satellites: Technologies of Receiving, Transmitting and Processing” (No. 2009/0231/1DP/ 1.1.1.2.0/09/APIA/VIAA/151). 


\title{
REFERENCES
}

1. Ābele, M., Ozols, J., Pavēnis, A., \& Vilks, I. (1998). Radioteleskopa RT - 32 pozicionēšanas datorvadība. Latv. J. Phys. Tech. Sci., (6).

2. Abele, M., Vilks, I., Bezrukov, D., \& Sika, Z. (2004). Measurements of the reflecting surfaces of RT -32 radiotelescope. Latv. J. Tech. Sci., (2), 46-53.

3. Nečajeva, M. (2010), private communication.

4. Žagars, J., Vilks, I. (2005). Astronomija augstskolām. Riga, ISBN 9984-770-60-5 (in Latvian)

5. Abele, M., Vjaters, J., Ubelis, A., Osipova, L. (2005). A telescope to spot space objects from the Earth surface. Latv. J. Tech. Sci., (3). 20-28.

6. Abalakin, N.K., Abele, M., Artykh, Yu.N., Basov, N.G., Bronnikov, V.N., Ignatenko, Yu.V., Kokurin, Yu.L., Kurbasov, V.V., Lapuska, K., Lobanov, V.F., Masevich, A.G., Sukhanovsky, A.N., Shilokhvost, Yu.P., Shubin, S.G., \& Yatskiv, Ya.S. (1985). Laser Network Designed for the Moon and Artificial Earth Satellite Ranging. Proceedings of the International Conf. on Earth Rotation and the Terrestrial Reference Frame, Ohio, Columbus (USA). pp. 246-256.

7. Abele, M., \& Osipova, L. (2004). Determination of NEO orbits based on laser ranging measurements. Latv. J. Tech. Sci., (1). 31-36.

8. Abele, M., Balklavs-Grinhofs, A., \& Osipova, L. (2004). A possibility of minor planets distance measurement with laser ranging device. Latv. J. Tech. Sci., (2), 54-61.

9. Abele, M., \& Osipova, L. (2006). Possibility of the Near-Earth Objects Distance Measurement with Laser Ranging Device. Proceedings of the 15th International Workshop on Laser Ranging, 444-449.

10. Abele, M., \& Osipova, L. (2008). Determination of minor planets orbits based on distance and velocity measurements. RTU Zinātniskie raksti, Geomātika. 62-72 (in Latvian).

\section{KOSMISKO OBJEKTU UN ZEMEI TUVO ASTEROĪDU TRAJEKTORIJU PRECIZĒŠANA AR LATVIJAS OPTISKAJIEM UN RADIO TELESKOPIEM.}

\author{
M. Ābele, L .Krūze, I. Šmelds, I. Eglīis, J. Kalvāns
}

$$
\text { Kopsavilkums }
$$

Par Zemei un kosmiskajai navigācijai bīstamiem objektiem tiek uzskatīti t.s. kosmiskie atkritumi - satelīti un satelītu daļas, kas vairs nepilda savas funkcijas, bet turpina lidot apkārt Zemei savās orbītās. Arī Zemes sadursmei ar kaut nelielu asteroīdu sekas var būt katastrofālas. Tāpēc ir ļoti svarīgi veikt šo objektu novērojumus un aprēķināt iespējamo objektu trajektoriju, lai prognozētu to iespējamo sadursmi ar satelîtu vai Zemi. Šajā darbā izvērtēts aprīkojums, ko Latvijas astronomi varētu izmantot, lai izsekotu Zemei tuvos objektus, kā arī noteiktu to orbītas un citus raksturlielumus. Veicot radio un lāzerlokācijas mērījumus, analizētas šī aprīkojuma iespējas. Secināts, ka Latvijas lielie radio un optiskie teleskopi ir piemēroti šo objektu izsekošanai un kustības parametru precizitātes uzlabošanai.

21.11.2011. 